\title{
The dynamics of the adoption of product and process innovations in organizations: a case study in Malopolska Voivodship
}

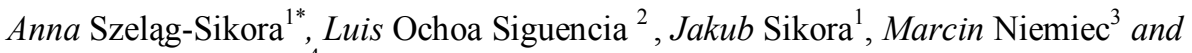 \\ Monika Komorowska ${ }^{4}$ \\ ${ }^{1}$ University of Agriculture in Krakow, Faculty of Production and Power Engineering, Balicka 116 B, \\ 30-149 Krakow, Poland \\ The Jerzy Kukuczka Physical Education Academy in Katowice, Faculty of Sport and Tourism \\ Management, 40-065 Katowice, Poland \\ ${ }^{3}$ Department of Agricultural and Environmental Chemistry, University of Agriculture in Krakow, \\ Mickiewicza Ave. 21, 31-120 Krakow, Poland \\ ${ }^{4}$ Department of Vegetable and Medicinal Plants, University of Agriculture in Krakow 29 Listopada Ave. \\ 54, 31-425 Krakow, Poland
}

\begin{abstract}
The research presented in this paper deals with issues related to the implementation of management and organizational innovations and their impact on the company's competitiveness. The target group of the study are enterprises from the micro- small and medium-sized enterprises (SME) sector based in the Malopolska Voivodship, which in the years 2011-2014 were beneficiaries of the project "Transforming enterprises into intelligent organizations - advisory support for companies Malopolska Voivodship" implemented by The Rabka Region Development Foundation under the Operational Program Human Capital (POKL), Measure 8.1 Development of employees and enterprises in the region, Sub-measure 8.1.1 - Supporting the development of professional qualifications and consulting for enterprises. The injection of knowledge from Mechanical engineering specialist and other specific areas of activity has a great impact in the development and modernization of the enterprises by introducing process, product, organizational or marketing innovations.
\end{abstract}

\section{Introduction}

When considering the issues of innovativeness, and especially the innovativeness of Small and Medium Enterprises in Poland, it can be seen that many innovative activities undertaken by these enterprises were in the form of product and process innovations and mainly related to the implemented of technological processes [1]. This make important the

\footnotetext{
*Corresponding author: anna.szelag-sikora@ur.krakow.pl
} 
role of high qualified Mechanical engineering specialist. Nowadays, much attention is paid to innovations implemented in the areas of organization, marketing and management, where sophisticated hardware and software has been implemented to make B2B, B2C and C2C more reliable [2].

Other of the areas that has suffered a huge changed are in the logistic innovations area and here will be important the role Mechanical engineering specialist will play.

The subject of the study are enterprises from the micro- small and medium-sized enterprises (SME) sector based in the Malopolska Voivodship, which in the years 2011-2014 were beneficiaries of the project "Transforming enterprises into intelligent organizations advisory support for companies Malopolska Voivodship" implemented by The Rabka Region Development Foundation under the Operational Program Human Capital (POKL), Measure 8.1 - Development of employees and enterprises in the region, Sub-measure 8.1.1 - Supporting the development of professional qualifications and consulting for enterprises. Innovations are a new value for the enterprise. The degree of novelty depends on the sophistication of the technical solutions used, originality of ideas, effectiveness of the management method, etc. Enterprises strive to create innovation with a high degree of novelty to achieve a competitive advantage [3-10]. A detailed description of the issue of innovation is presented in the Oslo Manual, created by OECD and Eurostat, distinguishing four types of innovation. These are: product, process, organizational and marketing innovations [11].

\section{Methodology}

The study uses the triangulation method of research techniques: computer-aided questionnaire (CAPI), individual in-depth interview (IDI) and participant observation. In the period 2015-2016, 50 entities were surveyed whose representatives agreed to participate in the second part of the study (second half of 2016) consisting in participation in individual in-depth interviews combined with participant observation.

The main goal of the publicly funded project was to identify and solve problems that hinder entrepreneurs functioning on the market, thanks to the advice of experienced experts. Advisory services were conducted by experts with many years of experience in cooperation with enterprises and in educational activities. Such an injection of knowledge from specific areas of activity is to develop and modernize the enterprise by introducing process, product, organizational or marketing innovations.

\section{Research results}

In the period 2015-2016, 50 entities were surveyed whose representatives agreed to participate in the second part of the study (second half of 2016) consisting in participation in individual in-depth interviews combined with participant observation. Owners / managers were asked to indicate to what extent the use of consultancy support influenced the innovative development of the enterprise transforming it into an intelligent organization.

As part of the project, entrepreneurs and their employees were offered consultancy support in specific thematic modules (Table 1) 
Table 1. Thematic modules of advisory support

\begin{tabular}{|c|l|l|}
\hline $\begin{array}{c}\text { Module } \\
\text { designation }\end{array}$ & \multicolumn{1}{|c|}{$\begin{array}{c}\text { Module } \\
\text { Name }\end{array}$} & \multicolumn{1}{|c|}{ Characteristic } \\
\hline $\mathrm{a}$ & Management & $\begin{array}{l}\text { customer relationship management, project } \\
\text { management, stimulation of creativity, incentive } \\
\text { programs, strategic management, time management, } \\
\text { conflict management, remuneration systems, marketing } \\
\text { strategies etc. }\end{array}$ \\
\hline $\mathrm{b}$ & Finances & $\begin{array}{l}\text { optimization of production / service costs, reading and } \\
\text { creating financial analyzes and reports, internal audits, } \\
\text { etc. }\end{array}$ \\
\hline $\mathrm{c}$ & Law & $\begin{array}{l}\text { labor law, business law, legal aspects of doing business } \\
\text { etc. }\end{array}$ \\
\hline $\mathrm{d}$ & Economy & $\begin{array}{l}\text { assessment of the effectiveness of the actions taken, } \\
\text { economic analysis of the implementation of innovation }\end{array}$ \\
\hline $\mathrm{e}$ & $\begin{array}{l}\text { Modern } \\
\text { technologies } \\
\text { including IT }\end{array}$ & $\begin{array}{l}\text { acquaintance with IT techniques, ways of obtaining } \\
\text { information, raising the level of company innovation, } \\
\text { data security management, ERP systems, production and } \\
\text { environment management systems, B2B, business } \\
\text { intelligence, industry solutions, etc. }\end{array}$ \\
\hline $\mathrm{f}$ & Other & \begin{tabular}{l} 
areas depending on the needs diagnosed \\
\hline
\end{tabular}
\end{tabular}

Source: own study based on project documentation

The consultancy hourly limit was set at $20 \mathrm{~h} /$ participant. The consulting did not cover investment processes or processes related to the company's current operating expenses. Each time an advisory service was preceded by a diagnosis of needs and an individual scope of actions taken as a result of the diagnosis.

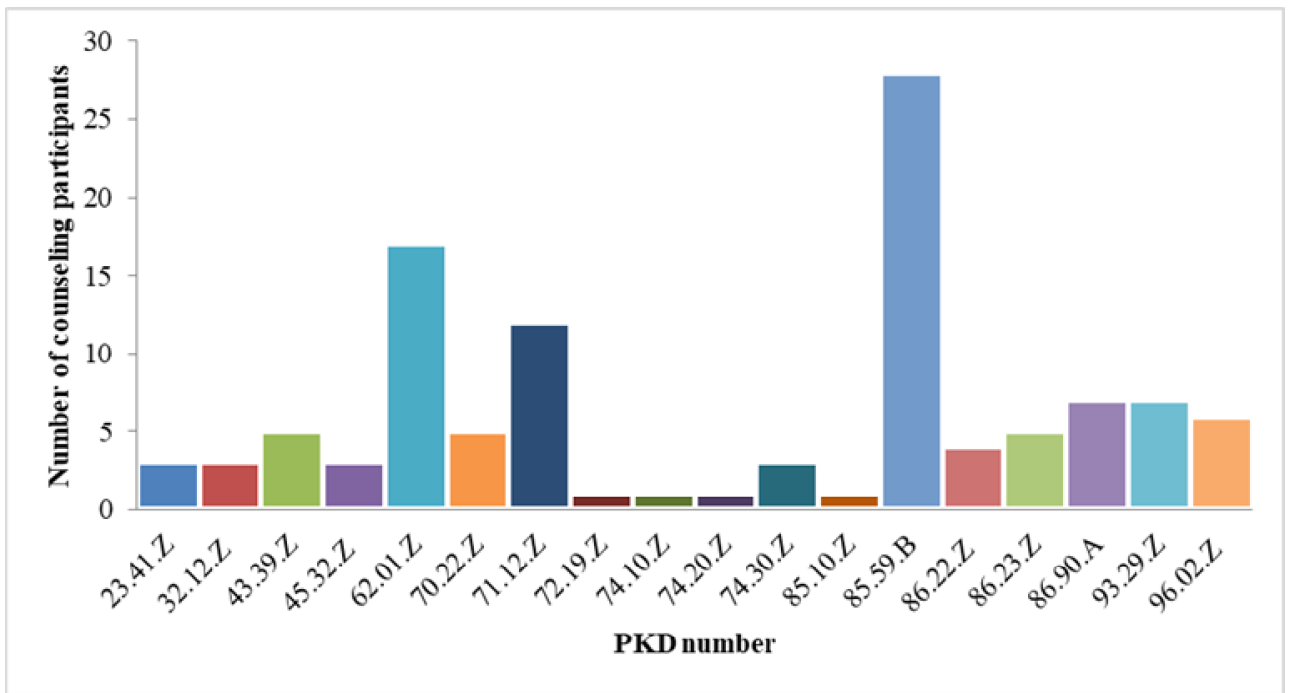

Fig 1. Participants of consultancy according to Polish Classification of Activities (Polska Klasyfikacja Działalności $=$ PKD) in 2007 
The most numerous representation in the studied group (Figure 1) were entrepreneurs providing non-school forms of education (PKD 85.59. B), conducting activities related to software (PKD 62.01.Z) as well as engineering and technical consulting (71.12.Z).

Analysing the structure of the share of individual support areas (Fig. 2) used by entrepreneurs, it should be noted that the areas of "a", "b", "c" and "d", which recorded a $20 \%$ share, enjoyed the greatest interest. A relatively low share was recorded in the " $\mathrm{f}$ " area (other areas depending on the diagnosis). This means that the diagnosed needs of enterprises in transforming the company into an intelligent organization focused on the issues defined as key consulting modules in the project.

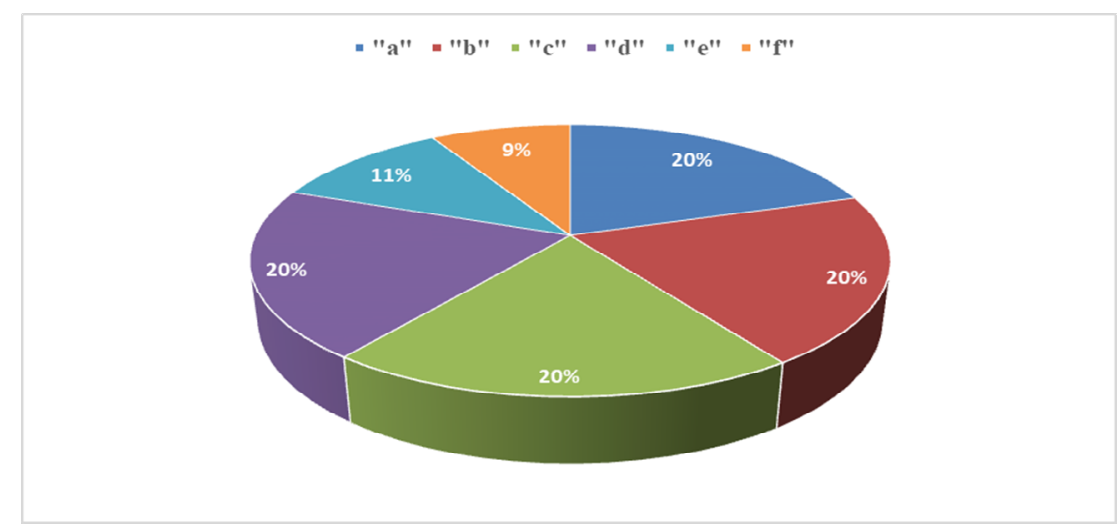

Fig. 2 Structure of the share of advisory support areas

Since each of the consultancy participants could take advantage of different thematic modules (effect of the diagnosis), it can be seen that each of the companies used consultancy in the areas of: management, finance, law and economics ("a", "b", "c", " d ').

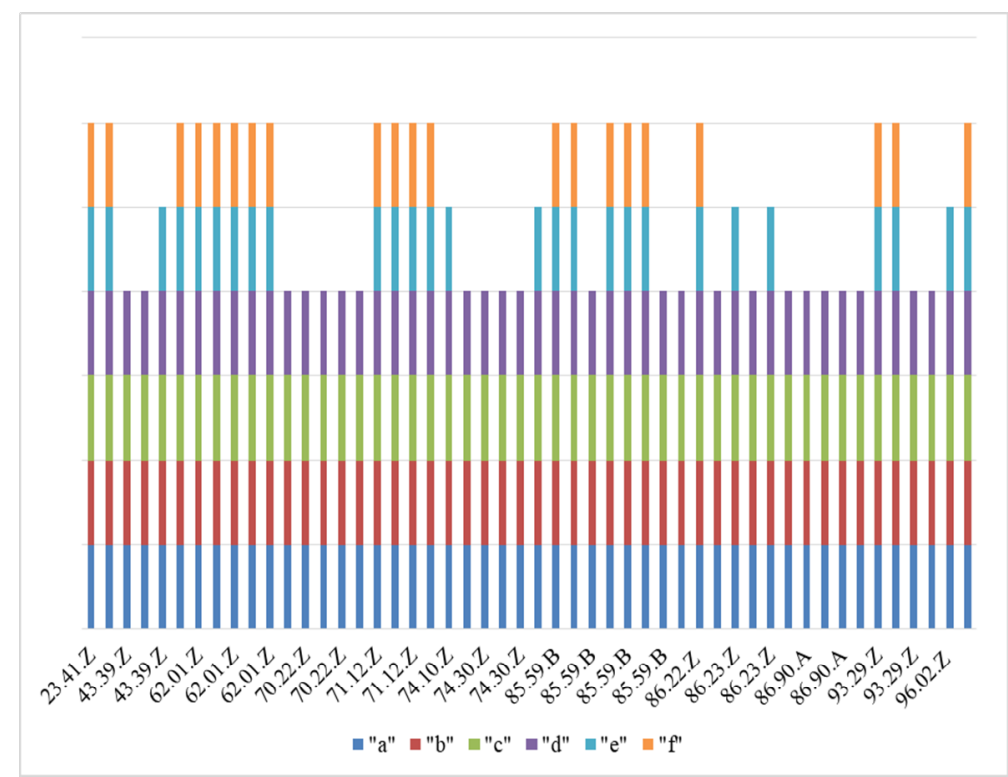

Fig. 3 Structure of the use of consultancy services by entrepreneurs (according to PKD 2007) 
As many as $86 \%$ of respondents considered the support received useful in making decisions in the area of innovative development of the enterprise. In the opinion of $14 \%$ of enterprises, the obtained advisory support was considered not useful (Fig 4). In an in-depth interview on the question clarifying why the decision to participate in the consultancy project was made, the entrepreneurs emphasized that the main determinant of the decision was the free support.

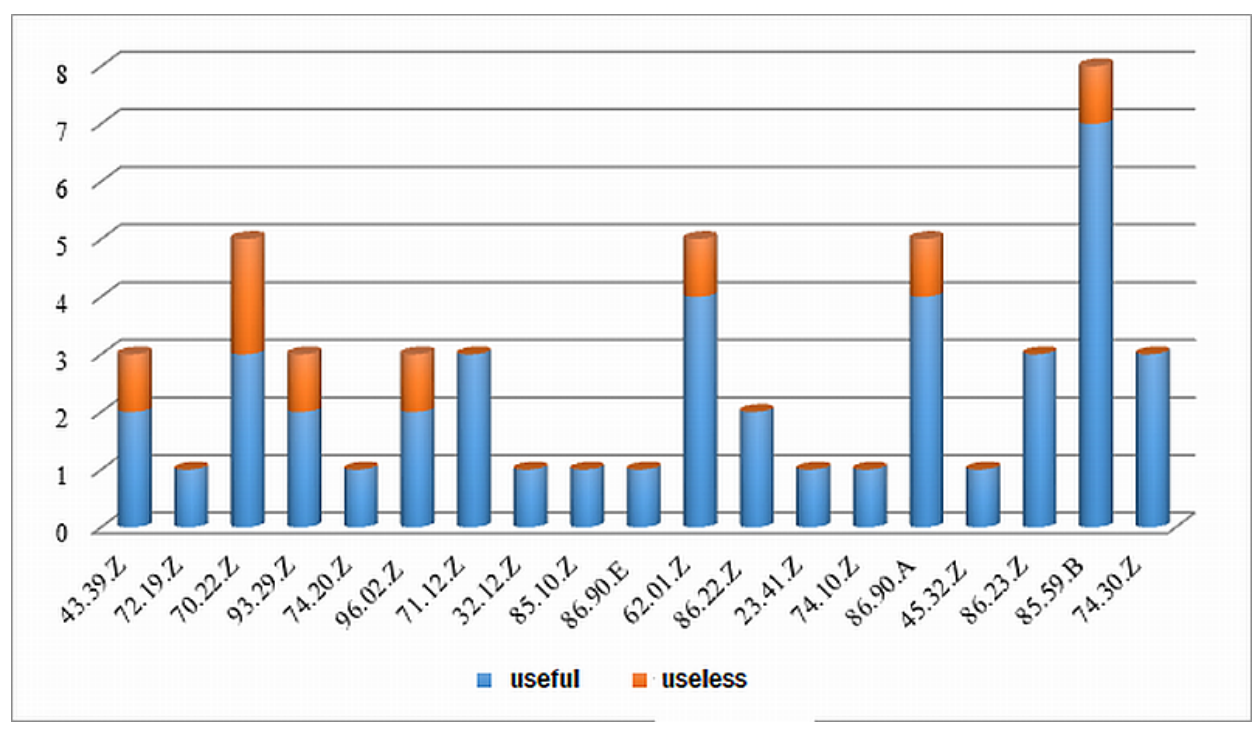

Fig 4. Usefulness of obtained support in innovative enterprise development

In the second part of the study, individual in-depth interviews were conducted combined with participant observation. The interviews were based on a unified collection of 8 open questions regarding the perception of the impact and importance of implemented innovative solutions on the functioning of the organization.

\section{Summary}

A change in the organizational culture components was observed in all enterprises that agreed to conduct research using the method of participant observation and follow-up interviews. The biggest change took place in the area of beliefs and expectations connecting employees of the analysed enterprises. They have become a factor integrating teams around intentional cooperation aimed at the widest possible use of the opportunities offered by innovative solutions. This demonstrates the progressive learning process of the organization leading to the transformation into intelligent organizations [12-15]. These companies tackled the problem of leadership based solely on the charisma of the leader and the bond united by fear. Employees of various levels who initiate or give opinions on new solutions were widely allowed to speak.

These enterprises no longer function as very formal. In addition to vertical information flows, the value system includes freedom of employee communication required ad hoc outside these structures. All the analysed enterprises (however to a different degree) develop values such as: customer satisfaction perceived as the basic value, decision-making shifted to lower levels and planned systematic product development. These changes 
resulted in noticeable changes in employee involvement and greater initiative. This is optimistic towards seeing work as an opportunity for self-realization.

\section{References}

1. Z. Gródek-Szostak, D. Kajrunajtys, L. Ochoa Siguencia. Society. Integration. Education. Proceedings of the International Scientific Conference. 6, 169, (2019).

2. M. Lin Tsai, \& Y. Yi Chen. International Journal of Ad Hoc and Ubiquitous Computing, 29, 28, (2018).

3. L. Ochoa Siguencia, (2018). Contemporary Information Technologies in Business Management. Publishing House of the Research and Innovation in Education Institute - Czestochowa (2018).

4. Z. Gródek-Szostak, Przegląd Organizacji, 11 (922), 10-15, (2016).

5. Z. Gródek-Szostak, A. Szeląg-Sikora, J. Sikora, M. Korenko, Business and Non-profit Organizations Facing Increased Competition and Growing Customers' Demands (Eds. A Ujwary-Gil, A Nalepka), Wyższa Szkoła Biznesu - National-Louis University, Nowy Sacz, 16, 427-439, (2017).

6. A. Szelagg-Sikora, J. Sikora, M. Niemiec, Z. Gródek-Szostak, J. Kapusta-Duch, M. Kuboń, M. Komorowska, J. Karcz, J. Sustainability,11, 5612, (2019).

7. Z. Gródek-Szostak, G. Malik, D. Kajrunajtys, A. Szelagg-Sikora, J. Sikora, M. Kuboń, M. Niemiec, J. Kapusta-Duch, J. Sustainability, 11, 4144, (2019).

8. J. Kapusta-Duch, A. Szeląg-Sikora, J. Sikora, M. Niemiec, Z. Gródek-Szostak, M. Kuboń, T. Leszczyńska, Borczak B. Sustainability, 11, 4008, (2019).

9. M. Niemiec, M. Komorowska, A. Szeląg-Sikora, J. Sikora, M. Kuboń, Z. GródekSzostak, J. Kapusta-Duch. Sustainability, 11, 3913, (2019).

10. A. Szelag-Sikora, Z. Gródek-Szostak, D. Kajrunajtys. Agricultural Producer Groups as an Example of Commercial Organizations in the Agricultural Sector (Eds. A. Krakowiak-Bal, M. D. Vaverková) Infrastructure and Environment, Springer, 318-324, (2019).

11. OECD, Oslo Manual. Rules for the collection and interpretation of data on innovation, Third Edition, 48-52, (2005).

12. Z. Gródek-Szostak, D. Kajrunajtys, O. Jando. Journal of Innovations and Applied Statistics, 8 1, 14-19, (2018).

13. J. Sikora, M. Niemiec, A. Szelagg-Sikora, Zofia Gródek-Szostak, Acta Scientiarum Polonorum. Administratio Locorum, 1, 83-92, (2017).

14. Z. Gródek-Szostak, D. Kajrunajtys, G. Malik, A. Szeląg-Sikora. European Journal of Service Management, 27 3-2, 175-181 (2018).

15. Z. Gródek-Szostak, L. Ochoa Siguencia, D. Kajrunajtys, Annals of Social Sciences \& Management Studies 2 3, 001-005, (2018). 